\title{
Some Wound Reactions in Filicinean Petioles.
}

\author{
BY \\ H. S. HOLDEN, M.SC., F.L.S. \\ Lecturer in Botany in the University College, Nottingham
}

With Plates LXXIII and LXXIV and one Figure in the Text.

\section{INTRODUCTION.}

$\mathrm{T}$ HE healing of wounds in phanerogamic tissues is normally accomplished by the production of either a callus or of a wound periderm. This subject has, on account of its economic value, long occupied a prominent place in botanical research, especially among experts in forestry and arboriculture, in whose province the question is naturally an all-important one. For similar reasons one finds that the occurrence of disease due to fungal agency has also received close attention, with the result that a considerable amount of literature has been produced bearing on these problems and their treatment, of which the works of Prillieux (23), Sorauer (28), Hartig (13), and Tubeuf (35), and more recently those of Duggar (9), Massee (17), and Smith (26), may be regarded as typical. In the case of the vascular cryptogams the investigation of wound response seems to have excited little interest, since any economic value is, in their case, absent.

The Bonn text-book (33) says of wound response in these forms, "The wounded cells die, and become brown and dry, whilst the walls of the underlying, uninjured cells become lignified' (pp. I50-1); it also briefly touches upon the formation of periderm in Ophioglossum (p. I48), a feature first noted by Holle (16), whose observation is also quoted by de Bary (8), and upon the formation of a pseudoperiderm in the Marattiaceae.

Incidental reference to a case of periderm formation is made by Chandler (4) for Polypodium aureum, while Stopes (30) and Seward (24) also refer to the healing of deep wounds in Calamitean axes.

Wound reactions of a somewhat different character are recorded by Strasburger (32), who describes the formation of tyloses in the carinal canals of Equiseta when the upper portions have been cut away, and by

[Annals of Botany, Vol XXVI. No. CIII. July, IgI2.] 
Weiss (36), who regards the abnormal proliferation in a Stigmarian rootlet, described by him, as due to a fungal attack.

The writer was fortunate enough to discover a case of superficial wounding in a Medullosean petiole, which had been repaired by the production of a typical wound periderm (14), and this led to an investigation of the reactions of Filicinean petioles to wounding, with a view to ascertaining whether similar phenomena were exhibited by these.

An incidental study of two cases of surface wounds in Cycadean petioles, those of Cycas circinalis and Bozvenia serratula, was also made in connexion with the present paper. These both showed the same type of response as the 'Myeloxylon' referred to, having to the outside a layer of dead, excised cortical tissue, immediately below which was a band of suberized cells, devoid of contents, and finally a mass of cambiform cells which merged into the typical cortical parenchyma (Pl. LXXIV, Fig. 2I).

\section{Methods.}

The investigations were commenced in the summer of 1909 at Manchester, where, owing to the kindness of Mr. Garnett, of Whalley Range, I was enabled to perform a preliminary series of experiments in his fernhouse. I should like to express here my appreciation of his unfailing courtesy, and my thanks for the facilities he granted me during the earlier portion of the work. Further series of experiments were performed during the spring and summer of 1910 and I9II, and a considerably increased number of forms was examined.

For purposes of investigation the petioles, where possible, were divided into three regions, as follows: (i) the curled apical portion, (ii) the region of pinna insertion, (iii) the region below pinna insertion; where special sterile and fertile segments occurred, as in Osmunda regalis and Allosorus crispus, both segments were examined.

It was thought that the nature of response would in all likelihood differ in the still actively growing apices and the maturer parts below, and, as the former did not appear to have been investigated in this connexion, would possibly reveal some points of interest.

The wounds were made with a sharp scalpel in each of the regions indicated, and were of a purely superficial nature, a thin shaving being removed which penetrated below the sub-epidermal layer of sclerenchyma characterizing most fern petioles, but did not seriously disturb the vascular supply. In those cases where the vascular supply was, accidentally, interfered with to any appreciable extent, it was found that various parasitic Fungi and Bacteria caused the complete rotting of the injured member, thus rendering it of little use for further study for this purpose.

The petioles thus wounded were allowed to continue growth for periods varying between a fortnight and fifteen weeks, and were then cut and at 
once preserved in chromo-acetic fixative, Perenyi, or Farmer's fluid. The number of forms examined in this way included the following species: Adiantum Capillus-veneris, A. Edgworthii, A. fulvum, Allosorus crispus, Asplenium Belangeri, $A$. bulbiferum, $A$. fontanum, $A$. viride, $A$. viviparum, Aspidium thelypteroides, Athyrium Filix-foemina, Blechnum brasiliense, Cystopteris bulbifera, C. fragilis, Dennstaedtia punctilobula, Davallia polyantha, Faydenia prolifera, Lastraea dilatata, L. Filix-mas, L. reflexa, L. thelypteris, Lomaria chilensis, Microlepia anthurifolia, Osmunda regalis, Phegopteris hexonaptera, Phlebodium (Polypodium) glaucum, Polystichum angulare, $P$. proliferum, $P$. falcatum, Pteris aquilina, $P$. cretica, Scolopendrium vulgare, Struthiopteris germanica, Woodwardia orientalis, $W$. radicans, $W$. virginica.

A large proportion of these were found to be much too hard in texture to microtome successfully, and consequently only sections of the apices of such were so prepared; some of the less resistant forms, however, offered little difficulty. The material was transferred from absolute alcohol, through pure cedarwood oil, to paraffin, as this method caused less shattering than when xylol was used. The harder forms were sectioned by hand. The best general results were obtained by double staining with carthamin and picric anilin blue, or safranin and Lichtgrün; for nuclear studies Heidenhain's iron-haematoxylin with a light erythrosin counterstain was satisfactory.

The microchemical investigation of the cell-walls and contents involved the use of special reagents, which will be dealt with in detail later.

\section{Results AND Discussion.}

The change in the external appearance of the affected surfaces, apart from a browning of the dead cells, was, as a rule, inconsiderable. In one or two cases, however, notably in Pteris cretica, the petiole became distorted and bent at the seat of injury (P1. LXXIV, Fig. 23), and the explanation of this seems to be that the removal of tissue had caused a violent disturbance of the osmotic balance. This had resulted in the flexure of the petiolar strand and the consequent crushing of the cortical parenchyma on that side of the strand remote from the wound.

With regard to the details of internal modification a systematic survey of the results obtained serves to demonstrate that, although no rigid scheme of classification of the various types of wound response is possible, there are yet certain underlying broad similarities and differences, correlated with the region of the wound and the texture of the petiole. Thus an almost solid deposit of gummy matter in the cells at the seat of injury is of practically universal occurrence, whilst the more or less widespread thickening of the cortical tissue is also a very frequent feature. 
It is a well-known fact that the tissues of many fern petioles are, even at maturity, of a comparatively delicate and parenchymatous character, a feature which is shared by all forms in their extreme apical portions, whilst others, such as Osmunda regalis and Davallia polyantha, are characterized, when mature, by an extremely tough, almost horny exterior, together with a highly developed sub-epidermal band of sclerized tissue, this rendering them very resistant. This tough character is doubtless a necessity in the large, upstanding forms, but is by no means confined to these, several of the small forms (e.g. Adiantum spp.) showing similar characters.

It appeared to the writer that, in this difference in the character of the more mature parts of the petiole, there occurred one of the features which lent itself to the grouping of the forms worked upon, and this proved to be the case, for it was only in what might be termed the softer bodied forms that any appreciable cell-growth, in response to injury of the maturer parts, occurred.

(i) Taking first the curled, apical region, it was found that practically the whole of the forms experimented upon showed attempts at cambium formation. This, in the most successful cases, resulted in the production of a complete wall of meristem in the injured area, and was found to occur in only a small number of the species examined, namely, Asplenium Belangeri, A. bulbiferum, A. viviparum, Polystichum proliferum, Woodwardia orientalis, and $W$.radicans. A reference to the figure (Pl. LXXIII, Fig. I) illustrating the wound meristem produced in the case of Polystichum proliferum will serve to demonstrate the complete nature of the healing. Here the wounded area has been completely traversed by an entirely new growth, several cells in depth, of typically cambiform cells with delicately granular contents. This growth is due to the elongation and division of the layers of cortical parenchyma abutting upon the wound, and has, in a few cases, rendered the identification of these primary units difficult, though in most parts the outlines of the original parent cells can still be determined.

The result of this continued elongation and division has been, in favourable cases, to produce at the originally flat, or slightly concave wound surface, a distinct convexity or intumescence (Pl. LXXIV, Fig. 20). The mode of growth of the affected cortical cells is well shown in specimens which have been allowed to grow for some time (nine or ten weeks). In these it is clear that the elongation is accomplished by a process of sliding growth somewhat analogous to that obtaining in the development of prosenchymatous elements, and often results in the production of a row of cambiform cells, of which the tcrminal members are somewhat longer than their fellows, and are bluntly conical in shape, thus enabling them to dovetail into the spaces between the divergent ends of their neighbours (Pl. LXXIV, Fig. I9).

A peculiar feature with regard to the cambial cells which lie at the 
actual surface of the injured area is that they show no traces of suberization upon their outer walls. They are, however, usually protected to a large extent by the scab-like remains of the cells originally injured when the wound was made, and it would appear that this has proved adequate. The brown appearance of the wound scar in most cases is due very largely to the remains of these tissues, though in the few petioles where suberization occurs the same effect is produced.

Immediately below the meristem proper there is a marked change in the character of the cells, which are much larger and possess abundant, coarsely granular contents. It will be seen that the most peripheral of these, that is, those which lie next to the cambial tissue, have also, in many cases, elongated somewhat, and have divided by a transverse wall suggesting an incipient attempt at cambium formation.

The features upon which I should like to lay emphasis in these specially active forms is, first, that there is an actual production of a complete pad of healing tissue, formed by the elongation and division of the cortical parenchyma, and second, that there is no evidence of the secretion of gummy matter in any of these species during the earlier stages of reaction.

It is a singular fact that the forms which exhibit the most successful attempts at the production of a healing tissue should be those in which the formation of bulbils for vegetative propagation is a characteristic feature.

It would seem that the production of these structures must necessitate the retention of a particularly mobile and responsive type of tissue, and this view receives strong support from the evidence afforded by the results obtained in other, non-bulbiferous, species of the same genera, in other softbodied forms, and by the nature of the response to injury in the maturer parts of the petioles of the same forms.

The young plantlets raised from the bulbils do not possess this power of regeneration to anything like so marked an extent as do the mature forms. In their case, in fact, an elongation of the cortical cells in the region affected, and the occasional division of these by a single transverse wall, suggesting cambial possibilities, seems to be the extent of their powers (P1. LXXIII, Fig. 2).

This evident contrast with the bulbil-producing petioles also lends strong support to the view that the cambial activity and the formation of reproductive buds are correlated, since the immature forms lack this power.

The elongation of the cortical cells, and their subsequent division to produce two or three daughter cells, would seem to be the most general type of response, and is a feature of the majority of the remaining forms examined. Thus in Lastraea Filix-mas, in Polypodium glaucum, and in 
Athyrium Filix-foemina there is a remarkable increase in the length and bulk of the cortical cells for a depth of from four to six cells, and these divide by one or more transverse walls, giving a distinctly meristematic character to the region, and affording a marked contrast to the cells which have not become secondarily active. Here, too, the suberization of the outer walls of the most peripheral cells has also taken place, thus affording adequate protection without interfering with their vitality (Pl. LXXIII, Fig. 3).

This stage of wound repair seems to be generally attained within three weeks of the infliction of the injury, but in the case of Asplenium Belangeri there was no trace of secondary activity in that period. Petioles of this species examined after three weeks showed a dry but in no way discoloured wound, and sections demonstrated that the collapse of the cells at the surface was the only response. In five weeks, however, the characteristic cambial development was perfectly obvious, and, apart from the slower rate of the early development, this species showed no striking points of difference from the remaining bulbiferous forms.

One form, Cystopteris bulbifera, however, appears to stand somewhat apart from the rest. The cortical cells of the petiole showed very little secondary activity either at the apex or below, but if a young, barely visible bulbil were cut off there was an appreciable cambial reaction. This is perhaps partially explicable in the comparative slenderness of the petiole, since this would be obviously more weakened by wounding than one of a more robust type, such as Asplenium viviparum.

The behaviour of Scolopendrium vulgare was also of some interest, as the cortical cells, for a much greater depth than the average, elongated, but on the other hand this was accompanied by a relative paucity of transverse divisions.

As the plant develops, and the originally curled portion becomes straight, secondary changes are involved. In one or two cases, however, plants of Lastraea Filix-mas which were wounded early, whilst they were still completely enveloped in ramenta, and collected eight weeks afterwards, before the spring period of rapid uncurling and growth had supervened, were found to show very little further modification. It is a noteworthy fact that all the hardy indigenous forms appear to show a more pronounced activity if wounded before the first great elongation of the petiole has taken place, the results with Lastraea, referred to above, with Athyrium Filix-foemina, and with Pteris aquilina, being specially marked (P1. LXXIII, Fig. 3).

This second type of apical wound response, with its inadequate attempts at cambium formation and its inability to produce a really efficient cellbarrier, affords a striking contrast to the condition characterizing Woodwardia radicans and its allies.

A still further reduction is shown in the attempt at healing made by Polystichum angulare, Pteris cretica, Lastraca reflexa, and Woodwardia 
virginica, in which only a single layer of cortical cells, namely, that consisting of the uninjured units immediately below the wound, exhibits any activity. This layer elongates quite appreciably, but generally shows no trace of cell-division (Pl. LXXIII, Fig. 4).

The superficial resemblance of these cells, both in Polystichum angulare and in the species which have previously been described, to the intumescences produced on the leaves of Hibiscus and other forms (Dale, 5, 6), led to a careful investigation of their cytology with a view to ascertaining whether there were any induced pathological nuclear phenomena. In a few cases cells were found to contain two nuclei, almost invariably in close proximity to one another, and in a considerable number of cells nuclei of abnormal shape, often showing a median constriction, were noticed (Pl. LXXIII, Fig. Io).

In Osmunda regalis, Blechmum brasiliense, and Struthiopteris germanica, which serve to illustrate the last gradation of wound response, there is very little or no elongation of the individual cells, and only very rarely a transverse division, but the outermost cells develop very early a strong suberization of their walls. These, and others of the hardestbodied forms, also show a band of lignified tissue immediately above the vascular structures, which, though dif-

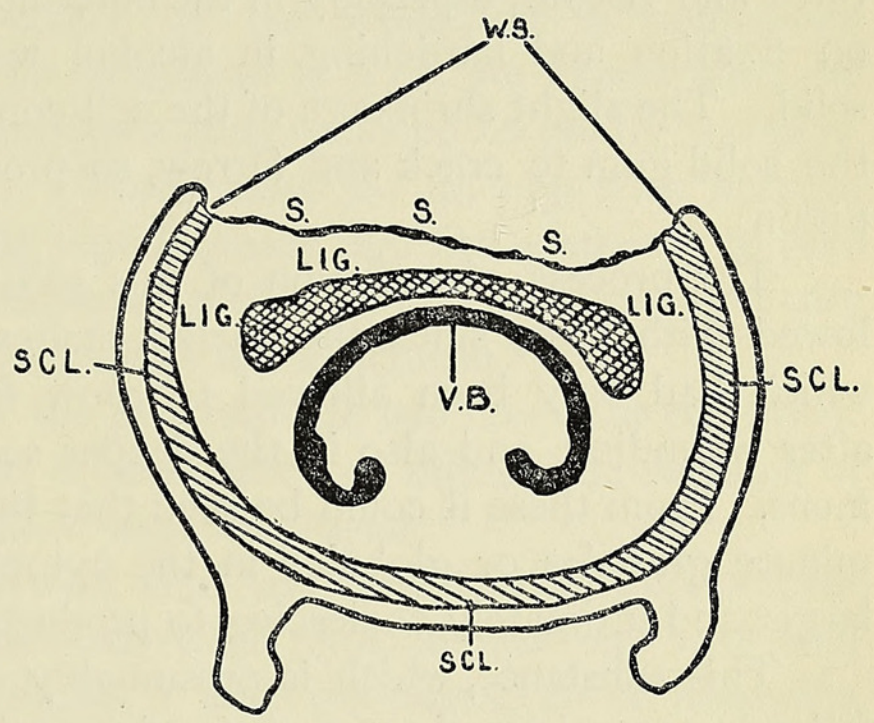

TEXT-FIGURE. Transverse section, young petiole of Osmunda regalis. SCL., sub-peripheral sclerenchyma; v. B., vascular bundle; W. s., wound-surface; s. s., suberized cells; LIG., cortical cells, secondarily lignified.

fering in structural detail from the sub-epidermal sclerenchyma, serves largely to replace this tissue as a protective sheath on the injured side (Text-figure).

From the foregoing examples it will be seen that a distinct and gradual series of forms is traceable, commencing with those producing a perfect pad of healing tissue such as Asplenium Belangeri and Polystichum proliferum, and passing through forms like Lastraea Filix-mas, with cellelongation and the production of an incipient cambium, to forms like Polystichum angulare, with cell-elongation alone, and finally to types like Osmunda regalis, in which cell-elongation and division are very infrequent, and where these are replaced by an efficient suberization and lignification.

The secondary changes which occur in the wounded apical areas as these unfold and become mature were found to be extremely variable, 
and to tend, in ultimate effect, towards the condition resulting from wounds of the second order, that is, those within the region of pinnainsertion.

In the bulbil-producing forms there were very marked changes: the cambiform cells had evidently ceased to divide and had become decidedly more thick-walled (Pl. LXXIV, Fig. I9), this thickening proving to be of a purely cellulose nature, whilst, in addition, the whole of the cortical tissues on that side of the stele adjacent to the affected surface had become filled with a gummy deposit (Pl. LXXIV, Fig. 20 b). This intracellular gum deposition was also a characteristic feature of all the remaining species, whether the cambial response had been still fairly strongly in evidence or not.

The gum, even in the fresh material before preservation, was extremely thick and viscous, especially in the outermost cells of the affected region, and on fixation and hardening in alcohol was found to have become quite solid. The slight shrinkage of the cell-contents had, in many cases, caused the solid gum to crack and furrow, so providing a ready means of recognition.

The process of secretion of this substance in the cells could be followed with ease, since the earlier stages were shown in the specimens which had only been allowed to grow for a comparatively brief period after wounding, and also in the deeper seated cells of the maturer specimens. From these it could be seen that the secretion was first produced as minute granules or globules in the cytoplasm, these gradually becoming larger and ultimately coalescing to produce an almost solid deposit.

This substance, which is presumably of a protective nature, gives the following reactions characteristic of wound gum :

I. It is insoluble in alcohol, chloroform, or benzol.

2. It is insoluble in hot or cold concentrated $\mathrm{H}_{2} \mathrm{SO}_{4}$.

3. It is insoluble in hot or cold concentrated solution of $\mathrm{KOH}$.

4. It stains deeply with alkannin, and with ruthenium red.

Treatment with thymol, orcinol, and phloroglucin gave, however, entirely negative results. It differs from wound gum also in the fact that it is intracellular, and does not appear to be due to any tissue degeneration, since even the cells in which the deposition is most complete show no traces of disintegration, and the nuclei do not appear to be adversely affected.

The cell-walls in the gum-secreting zone invariably increase in thickness, but this, in different forms, and even different specimens of the same form, varies considerably in its microchemical reactions.

In practically all species the outermost cells gave a pure cellulose reaction with chlor-zinc-iodine, and absolutely negative results with phloroglucin and $\mathrm{HCl}$, and other lignin-demonstrating reagents. This is easily understood in those petioles where the cells show elongation and division, 
Holden.-Some Wound Reactions in Filicinean Petioles. 785

as lignification would obviously interfere with their growth, but where the elongation is slight in amount or absent, the explanation does not seem at all clear.

The inner layers were also occasionally of cellulose, but more commonly showed distinct evidences of lignification, giving a pink colour with phloroglucin after acidification with $\mathrm{HCl}$. The depth of the coloration indicates a very imperfect lignification, the walls being of a ligno-cellulose rather than a true lignin nature. In other cases the lignification had become much more pronounced, giving the typical bright red phloroglucin coloration and in some of the smaller petioles extending throughout the cortex.

The modified cells, especially in the immediate vicinity of the wound, were coloured yellow or yellow-brown by the deposition of tannin-like substances in their walls, and, as this interfered to a certain extent with the action of the various reagents, it was, as a rule, removed by gently warming the sections with eau de Javelle. Zimmermann (37, p. 143) cites Mangin as stating that treatment with this liquid causes lignified elements to give the cellulose reactions, but in the experience of the writer, if reasonable care is observed, this is certainly not the case in the Filicineae.

As a test of the reliability of the phloroglucin reaction after treatment of the tissues with eau de Javelle, several series of microtome sections of a wounded petiole of Lastraea reflexa were employed.

Half of these were acidified with $\mathrm{HCl}$ and then treated with phloroglucin solution, whilst the remainder were first decolorized with eau de Javelle and then similarly treated. The coloration, apart from the yellowness of the walls of the most peripheral cells, was identical in each case, the xylem elements being bright red, whilst the imperfectly lignified cortical tissue was stained pink. The walls of the modified cells are abundantly pitted, though the pits themselves are not large; they are shown very clearly on swelling with caustic potash (Plate LXXIII, Fig. 8).

(ii) With regard to the reactions of the tissues in the regions below the apex, the same variability is noticeable in the different forms, but to a less degree.

A section of a wounded area produced just below the curled apex in Asplenium bulbiferum exhibited a slight elongation of the cortical cells, accompanied by a large number of cambial divisions, this resulting here and there in the production of a small tabulate cell. There was not, however, any attempt at the production of a complete new growth. The cells at the periphery showed what seemed to be slight traces of suberization, but the tests for suberin gave results which could only be described as extremely inconclusive (PI. LXXIII, Fig. 5).

Similar cambial activity, to a perhaps slightly less extent, was perceptible in the middle of the fully unfolded pinna-bearing region of all the 
bulbiferous species examined with the exception of Cystopteris bulbifera and Adiantum Edgworthii, but gum did not begin to make its appearance until the lapse of from four to five weeks (PI. LXXIII, Fig. 6).

In one case, however, in which a plant of Woodwardia radicans had accidentally been kept without water, the gum deposit was abundant within a fortnight, and there were practically no traces of either cellelongation or cambium formation.

Two specimens of Woodwardia orientalis were also somewhat exceptional in that for a considerable depth the affected tissues after division became suberized (Pl. LXXIII, Fig. I I).

That actual suberization and not merely a deposit of tannin in the tissues had occurred was amply demonstrated by the following reactions:

I. The cell-walls were insoluble in hot or cold concentrated $\mathrm{H}_{2} \mathrm{SO}_{4}$.

2. They were only dissolved with difficulty by a strong solution of chromic acid.

3. They stained readily with cyanin, with alkannin, and with fresh chlorophyll solution after removal of the tannin with eau de Javelle.

4. They stained brown-violet with chlor-zinc-iodide after treatment with $\mathrm{KOH}$ solution.

5. They were doubly refractive with polarized light.

It was at first a source of difficulty to understand how the suberization could be so complete, and the cells yet retain their contents after three months apparently but little affected.

Staining with cyanin, alkannin, and chlorophyll, however, showed the presence of abundant pits in the walls, these showing especially well where the walls had been cut tangentially, and doubtless serving to ensure protoplasmic continuity.

An abundant deposit of gum was a general feature in all the remaining cases, but there were certain differences apparent in the mode of repair.

In Athyrium Filix-foemina, Lastraea reflexa, and most of the remaining species there was a certain amount of cell-elongation, with an occasional transverse division in a few forms, but this was seldom pronounced. It was always accompanied by an increase in the thickness of the walls, this usually being of a ligno-cellulose character.

The species of a more horny nature, such as Pteris cretica, Blechnum brasiliense, and Polypodium glaucum, varied somewhat, specimens occasionally showing some elongation, but more commonly contenting themselves with a thickening of the walls and a dense aggregation of gum. The modified walls in these also were often slightly lignified, and in one or two instances the lignification was strongly marked. In Lomaria chilensis and Phegopteris hexonaptera the lignification extended throughout the petiole in the wound area. Osmunda regalis and Struthiopteris germanica as a rule behaved similarly to the above forms, but in one or two instances, in the 
large mature petioles, the reaction was quite different, and was similar to that constantly resulting in Davallia polyantha and Adiantum spp. Here the peripheral cells became brown and enormously thick-walled with large pits for protoplasmic connexions, the thickening becoming less pronounced as the cells became further from the wound until they merged into the normal cortical parenchyma (Pl. LXXIV, Fig. I2).

Microchemical investigation demonstrated that this thickening was also peculiar in consisting throughout of pure cellulose. As in previous cases, the outermost cells showed a solid deposit of gum, whilst those near the exterior also showed large quantities of granular matter.

The reaction produced in Scolopendrium vulgare, which is soft bodied and possesses an undivided leaf, was exceptional. The parenchymatous cells extending through fully half the diameter of the cortex, and in some specimens even partially round the vascular bundle, had, under favourable circumstances, without actually dividing, elongated to a very considerable extent, producing exaggerated intercellular spaces owing to the partial separation of adjacent cells (P1. LXXIII, Fig. 9). The result of this lengthening is that a slight intumescence is formed, comparable to those produced as a consequence of traumatic stimulus in the case of many roots (Nêmec (20), Bayliss (1), Davis (7)).

No amitotic nuclear divisions were observed, though the majority of those in the cells affected were spindle shaped, and some showed a median constriction (Pl. LXXIII, Fig. IO). The number of cells which were completely filled with gum was exceptionally large, these extending inwards to a depth of six or more, and, as in previous cases, the cells below also showed abundant granules.

From these facts it will be perceived that there is in the pinna-bearing region a distinct loss of cambial activity, the bulbil-producing species of Asplenium, Polystichum, and Woodwardia being the only ferns among those examined which still show any marked efforts in this direction.

The tissues developed during the formation of 'pneumathodes' which characterize the rhizome and stipules of the Marattiaceous ferns as figured by Hannig (12), offer a remarkable analogy to those produced in the wounded areas in the pinna-bearing parts of the bulbiferous species referred to.

In the remaining species examined the general mode of response takes the form of local thickening, either of cellulose, ligno-cellulose, or lignin, of the tissues at the seat of injury, this being accompanied by a greater or less amount of cell-elongation and division, and an abundant deposit of gummy matter.

(iii) In the petiole below the region of pinna-insertion, the tissues of which may be regarded as quite mature, there is an almost uniform response to wounding. Here there is no elongation of the cortical elements in normal cases, thickening and the production of gum in large quantities 


\section{Holden.-Some Wound Reactions in Filicinean Petioles.}

being general. In one case only, and that of a decidedly exceptional nature, was any secondary growth observed. This exceptional case occurred in the basal part of the petiole of Woodwardia orientalis, and was apparently due to bacterial infection.

The petiole showed a pronounced local dilatation in the wound area (P1. LXXIV, Fig. I3), and on microscopic examination it was found that the uninjured cortical cells at the wounded surface had proliferated in a peculiar, irregular manner, giving rise to a well-marked intumescence (Pl. LXXIV, Fig. I4).

The cells had, in some cases, especially at the margins of the affected area, grown very long without dividing, whilst the remainder had divided up by transverse walls at varying intervals, and the resultant daughter cells had also grown. The appearance of these cells was very different from that produced by ordinary cambial division. The whole of the cells were filled with cytoplasm of a cloudy nature, and in addition contained minute rods, which were presumably the cause of the growth. Cells containing two nuclei were not uncommon, and in one or two of the largest cells three nuclei were detected (P1. LXXIII, Fig. IO).

Strasburger (34) records somewhat similar instances of cells containing several nuclei in the case of graftings where tissues have been injured.

Hypertrophy as a result of infection by Bacteria is not uncommon, the root-nodules produced in Leguminosae, Almus, and Myrica being typical instances, whilst Smith (27) has also described local swellings produced on the olive due to similar causes.

Immediately below the meristematic zone there was a large patch of tissue several cells in diameter which had become strongly impregnated with tannin, this cutting off the infected cells from the general mass of cortical tissue (Pl. LXXIV, Fig. I4).

Appearances point to this being of the nature of a protective wall since the rodlets were not detected in any of the cells within this zone.

The results obtained in the basal petiolar region are precisely what might have been anticipated from a comparative study of the effects of wounding in the younger parts. As the petiole becomes absolutely set and mature the stimulus causing anything but the simplest form of response, that is, local thickening, would have to be of a very unusual character, a condition fulfilled in the abnormal case recorded.

The description of the various reactions recorded has been confined to the results produced in the general mass of cortical parenchyma, and as the remaining tissues appear to each show considerable uniformity it has been thought preferable to deal with them separately.

(a) The epidermis in the most freely reacting forms (e.g. Asplenium Belangeri) showed a certain amount of sliding growth in the wound area accompanied by one or more cell-divisions, this 
resulting in a callus-like incurving at the margins somewhat similar in appearance to the early stages of repair seen in trees after a branch has been severed (P1. LXXIV, Fig. 20). In the remainder the epidermal cells nearest the wound showed at the most an increase in general bulk rather than elongation in any particular direction, and were usually filled with gum (Pl. LXXIV, Fig. I6). The walls did not exhibit any additional growth in thickness in any case.

(b) The vascular bundle and bundle-sheath. Whenever a bundle was cut into to any great extent, degeneration of the tissues and a general deposit of coarse, brown, granular matter seemed invariably to result. Where the bundle-sheath was not actually cut away the cells on the side adjacent to the wound showed a growth in length and also division, this often leading, where the sheath did not show radial thickenings, to loss of identity as a definite layer. Where radial thickenings were present the daughter cells resulting from the division also showed these (Pl. LXXIV, Fig. 20).

The endodermal cells of some forms (e. g. Davallia) are characterized by heavy brown thickenings, but these do not seem to be in any way affected by wounds, the bundle-sheath of parts remote from the wound showing an amount of thickening equal to those nearer to it (Pl. LXXIV, Fig. I5). With regard to the phloem and xylem, where the differentiation of these elements is already complete no traumatic effects are perceptible, but where, as in the apical portions, the lignification of the later-formed xylem elements has not begun, both this and the phloem show distinct elongation towards the affected part. The cells of the phloem and of the bundle parenchyma often show both elongation and transverse division; in the case of the large xylem elements elongation alone occurs. That this elongation is of the nature of traumatic response, and is not due to the disturbance of the bundle symmetry by the departure of a leaf-trace, is strongly supported by the fact that specimens wounded on the abaxial side of the petiole show this feature very markedly (P1. LXXIV, Fig. I7).

From the foregoing it will be perceived that the more specialized tissues, such as the epidermis, the endodermis, and the vascular elements, are all responsive to a greater or less extent to traumatic stimuli, but that, as might be expected, the modification is of a much less pronounced character than that obtaining in the comparatively simple cortical parenchyma.

A first series of experiments such as these are almost of necessity incomplete, since the aim has been to obtain a general idea of the mode of response to wounding in the Filicineae as a group, rather than a detailed knowledge of the behaviour of one or more species. As a result the effect of varying physiological conditions has not been studied, except incidentally.

With the exception of a few of the hardiest forms, such as Pteris 


\section{Holden.-Some Wound Reactions in Filicinean Petioles.}

aquilina and Lastraea Filix-mas, the plants were grown under glass and under practically identical conditions. The writer hopes to make the physiological aspect of the paper the subject of a subsequent investigation.

\section{SumMary.}

I. When a fern petiole is wounded in the still meristematic apical zone, the plant attempts to protect the injured area by the production of a pad of cambiform cells, which arise by the subdivision of the cortical parenchyma.

2. In the most successful cases the wound-cambium completely covers the affected part with a typically meristematic tissue, as in Asplenium bulbiferum, A. Belangeri, Polystichum proliferum, Woodwardia orientalis and $W$.radicans.

3. More usually the cambial response is imperfect, consisting of the elongation of the cells at or near the seat of injury, with a greater or less number of transverse divisions of these (e. g. Lastraea Filix-mas, Polypodium glaucum, Scolopendrium vulgare). In Polystichum angulare, Pteris cretica, Lastraea reflexa, and Woodwardia virginica, elongation of the outermost layer alone occurs.

4. The cambium, whether well developed or imperfect, is supplemented by the scab-like remains of dead cortical cells on the outside.

5. As the petiole develops secondary changes take place, resulting in the thickening of the cell-walls by deposits of cellulose, ligno-cellulose or lignin, and in the deposit of an almost solid mass of intracellular gum.

6. Petioles wounded in the more mature ' region of pinna-insertion ' produce cambium less readily, only those producing bulbils, of the forms examined, showing this mode of response in any marked degree.

7. It is suggested that the production of bulbils may demand a more adaptable type of tissue, this accounting for the readiness with which cambium is produced.

8. In other forms, elongation of the outer cells, together with an abundant deposit of gum, is the most general type of wound response. Transverse divisions of the modified cells are few in number or do not occur.

9. Occasionally, as in Davallia polyantha, there may be an extremely thick deposit of cellulose on the walls of the cells at the seat of injury, resulting in the production of a very resistant tissue. Gum is deposited as in the previous cases.

Io. Plants wounded in the basal part of the petiole generally show no cell-elongation, but thickening of varying character together with a constant deposit of gum were constant features.

II. In only one case, an abnormal one, in which the wound was infected by Bacteria, was any secondary activity evinced. This resulted in the local 
dilatation of the petiole, and the formation of a distinct intumescence by the irregular division of the infected cells.

I2. Where cell-elongation occurs, pathogenetic, amitotic nuclear division, either complete or incomplete, may accompany this.

I3. The epidermis in the most active species may show sliding growth comparable to that exhibited by the cortical cells, but usually, beyond an abundance of gum and an increase in the size of the cells, little sign of activity is shown.

14. The cells of the endodermis either enlarge or elongate, and may divide so that their identity as a definite layer is lost on the side nearer the wound, when this approaches the bundle at all closely.

I5. There is some evidence that the phloem and xylem, when young, are influenced by wounding, and elongate towards the seat of injury.

In conclusion, the author's thanks are due to Professor Weiss for much encouragement and help; to Professor Carr, in whose department the major portion of the work has been done, and who has permitted his plant-house to be used for the experimental work ; to Mr. S. Garside, M.Sc., lately of the Victoria University, Manchester, who kindly collected and preserved part of the material used; and to Miss Bancroft, B.Sc., who performed a series of control experiments on a number of the hardier forms, whilst studying at the University College, Nottingham.

\section{BIBLIOGRAPHY.}

1. Bayliss, J. S.: On the Galvanotropism of Roots. Ann. Bot., xxi, I907.

2. Brebner, G. : On the Anatomy of Danaea and other Marattiaceae. Ann. Bot. xvi, 1902.

3. Butler, O.: A Study on Gummosis of Prunus and Citrus, \&c. Ann. Bot. xxv, I9li.

4. Chandler, S. E. : On the Arrangement of the Vascular Strands in the 'Seedlings' of certain Leptosporangiate Ferns. Ann. Bot., xix, 1905 .

5. DALE, E. : Investigations on the Abnormal Outgrowths or Intumescences on Hibiscus vitifolius. Phil. Trans. Roy. Soc. B, vol. cxciv, I90I.

6. $\quad$ Further Experiments and Histological Investigations on Intumescences, with some Observations on Nuclear Division in Pathological Tissues. Phil. Trans. Roy. Soc. B., vol. cxcviii, 1906.

7. Davis, H. V. : Notes on Certain Intumescences in Roots. New Phyt., ix, I9Io.

8. DE BARY, A.: Comparative Anatomy of the Phanerogams and Ferns. Eng. edit., Oxford, 1884 , p. 108 .

9. Duggar, B M.: Fungous Diseases of Plants. Boston, 1909, pp. 103-34 incl.

10. Frank, A. B.: Die Krankheiten der Pflanzen. Breslau, 1896.

11. Goebel, K.: Organography, vol. i. Eng. edit., Oxford, 1900, p. I97.

12. Hannig, E.: Ueber die Staubgrübchen an den Stämmen und Blattstielen der Cyatheaceen und Marattiaceen. Bot. Zeit., lvi, Abt. I, I 898.

13. HARTIG, R. $\vdots$ Text-Book of the Diseases of Trees. Revised by H. Marshall Ward, London, I 894 . 
14. Holden, H. S. : Note on a Wounded Myeloxylon. New Phyt., ix, i9io.

15. : Preliminary Note on Periderm Formation in Filicinean Petioles. Ann. Bot., xxiv, I9 Iо.

16. Holle, H. G. : Ueber Bau und Entwicklung der Vegetationsorgane der Ophioglossaceen. Bot. Zeit., 1875 .

17. Massee, G.: Diseases of Cultivated Plants and Trees. London, i9ro.

18. Masters, M. T.: Vegetable Teratology. Ray Society Publications, I869.

19. Mонц, H. von: Vermischte Schriften: Ueber den Bau des Stammes der Baumfarne. I845.

20. Nemec, B.: Studien über die Regeneration. Berlin, I905.

21. Potter, M. C.: On a Bacterial Disease of the Turnip. Proc. Roy. Soc., I9oo.

22. - A Brief Review of Bacteriological Research in Phytopathology. Science Progress, xviii, I9I0.

23. Prillieux, E. : Maladies des plantes agricoles, vol. i. Paris, 1895.

24. Seward, A. C. : Fossil Plants, Part I. Cambridge, I898, pp. 319-20.

25. Smith, C. O. : A Bacterial Disease of the Oleander. Bot. Gaz., xlii, I9o6.

26. Sмiтн, E. F. : Bacteria in Relation to Plant Diseases. Pub. Carnegie Inst., Washington.

27. - Recent Studies of the Olive-tubercle Organism. Bureau of Plant Industry, U. S. Dept. Agricult., Bull. cxxxi, 1908.

28. Sorauer, P.: Pflanzenkrankheiten. Berlin, I889.

29. Stevens, W. C.: Plant Anatomy. Second Edition, London, I9io.

30. Stopes, M. C. : A Note on a Wounded Calamite. Ann. Bot., xxi, 1907.

31. - Adventitious Budding and Branching in Cycas. New Phyt., ix, I9Io.

32. Strrasburger, E. : Leitungsbahnen: Jena, i 89 I. Der Bau der Kryptogamen, pp. 43I-43.

33. — : Text-Book of Botany. Third Eng. edit., London, I908, pp. I48, I50-I.

34. : Meine Stellungnahme zur Frage der Pfropf bastarde. Ber. d. deutsch. bot. Ges., Bd. xxvii, I909.

35. Tubeuf, K. F. von, and Smith, W. G. : Diseases of Plants induced by Cryptogamic Parasites. London, I 897 .

36. Weiss, F. E. : A Probable Parasite in a Stigmarian Rootlet. New Phyt., iii, I904.

37. ZimmermanN, A.: Botanical Microtechnique. Eng. ed., I904.

\section{EXPLANATION OF PLATES LXXIII AND LXXIV.}

Illustrating Mr. Holden's paper on Wound Reactions in Filicinean Petioles.

\section{PLATE LXXIII.}

Fig. I. Polystichum proliferum. Curled apex in transverse section, showing formation of a complete wall of cambiform tissue. $\times 250$.

Fig. 2. P. proliferum (young). Curled apex in transverse section, showing elongation of the outer cortical cells, and occasional transverse divisions. Slightly diagrammatic. $\times 250$.

Fig. 3. Lastraea Filix-mas. Curled apex in transverse section, showing elongation and division of the cortical cells. Slightly diagrammatic. $\times 25^{\circ}$.

Fig. 4. Polystichum angulare. Curled apex, showing elongation of outermost cortical cells only, without division. Slightly diagrammatic. $\times 25^{\circ}$.

Fig. 5. Asplenium bulbiferum. Transverse section of petiole just below curled apex. $\quad \times 25^{\circ}$.

Fig. 6. A. bulbiferum. Transverse section of petiole in region of pinna-insertion. $\times 25^{\circ}$.

Fig. 7. Lastraea Filix-mas. Transverse section of petiole in region of pinna-insertion. One side shows cell-contents, the other the elongation and division of the cortical cells and the thickening of the walls. $\times 250$. 
Fig. 8. L. Filix-mas. Small portion of section, showing solid deposit of gum traversed by cracks, also neighbouring cells with granules; one cell shows the pits in the wall in surface view. $\times 600$.

Fig. 9. Scolopendrium vulgare. Transverse seçtion of petiole in region of pinna-insertion, showing cell elongation for an exceptional depth. $\times 250$.

Fig. Io. Cells from various forms, showing pathological nuclear effects. $a, b$, Lastraea Filixmas; $c, d, e$, Scolopendrium vulgare ( $d$ and $e$ show gum deposits); $f$, Woodrvardia orientalis, with Bacteria. $a-f, \times 750$.

Fig. 11. Woodrwardia orientalis. Transverse section of petiole in region of pinna-insertion, showing division and suberization of cortical cells. $\times 25^{\circ}$.

\section{PLATE LXXIV.}

Fig. I2. Davallia polyantha. Transverse section of petiole below region of pinna-insertion. The cortical cells are heavily thickened, the outer ones contain abundant gum, and the connecting pits are well marked. $\times 25^{\circ}$.

Fig. I3. Woodrwardia orientalis. Petiole infected by Bacteria, showing local dilatation. $\times \mathbf{I}$.

Fig. 14. W. orientalis. Transverse section of infected area of same with suberized layer below. $\times 250$.

Fig. I5. Davallia polyantha. Small portion of petiole, showing difference in character of endodermal thickenings and those of other parts of the cortex. $\times 600$.

Fig. 16. Scolopendrium vulgare. Small portion of epidermis to show slight growth of deposit of gum, due to wound stimulus. $\times 500$.

Fig. I 7. Polystichum proliferum. Single vascular bundle from extreme apex, showing effect of wounding on young phloem and xylem-elements. $\times 600$.

Fig. 18. Woodwarilia orientalis. Small portion of infected petiole in Fig. I3, showing edge of wounded area. $\times 400$.

Fig. 19. Asplenium Belangeri. Small portion of cortical parenchyma of wounded apex, illustrating method of growth of secondarily active cells. The intercellular spaces are darkened. $\times 600$.

Fig. 20. A. Belangeri. (a) Curled apex of petiole in transverse section to show division of cortical cells, epidermis, and endodermis. Slightly diagrammatic. $\times 300 . \quad(b)$ Diagram showing area (lightly shaded) containing gum deposit.

Fig. 2I. Bowenia serratula. Portion of petiole in transverse section, showing true wound periderm. Specimen from Kew. $\times$ I 20.

Fig. 22. Pteris cretica. Petiole, showing flexure due to wounding. $\times 1$.

Fig. 23. Woodzuardia virginica. Transverse section of petiole, showing cell-elongation and slight cellulose thickening. $\times 400$. 
Annats of Botany,
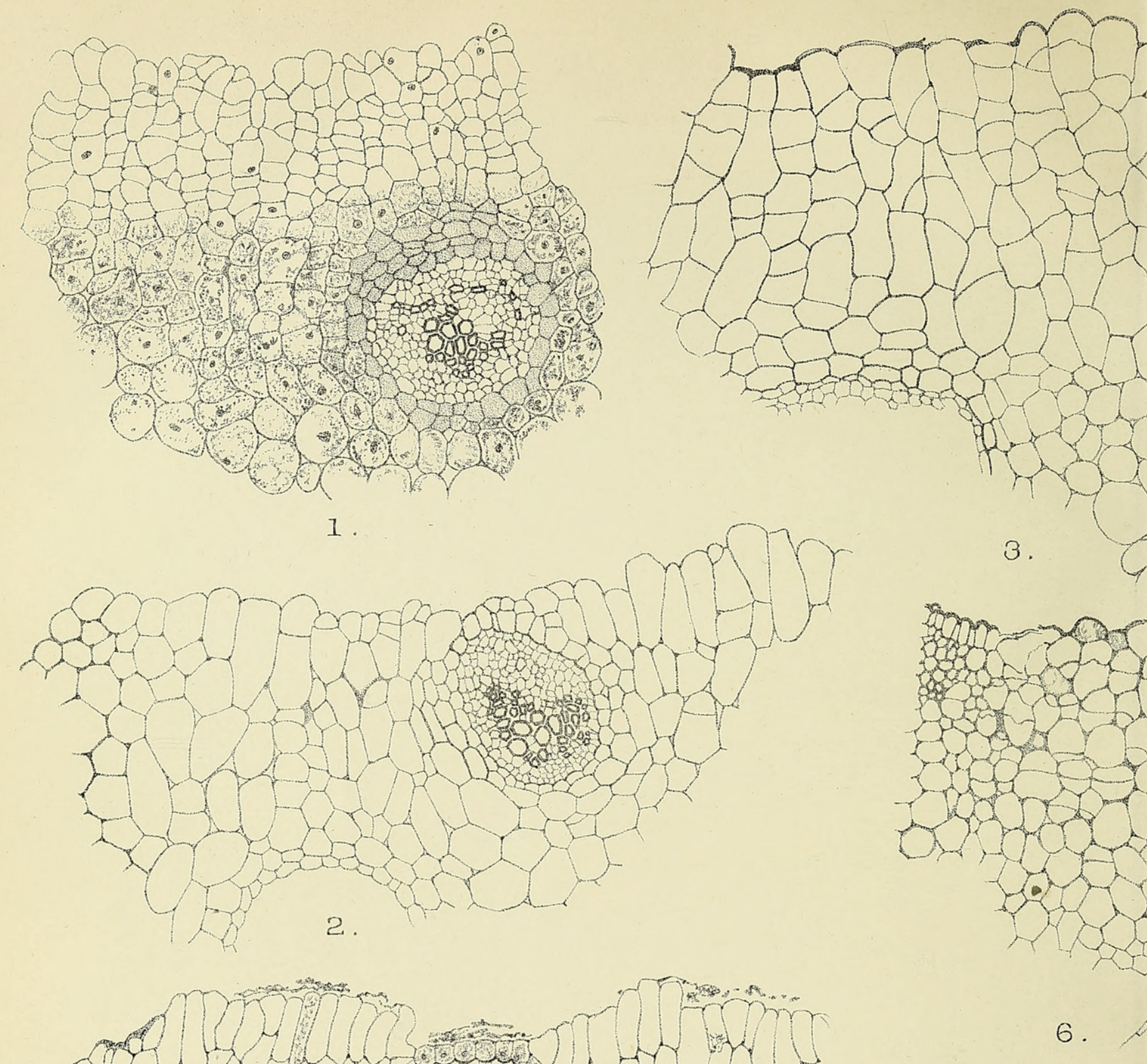

3.
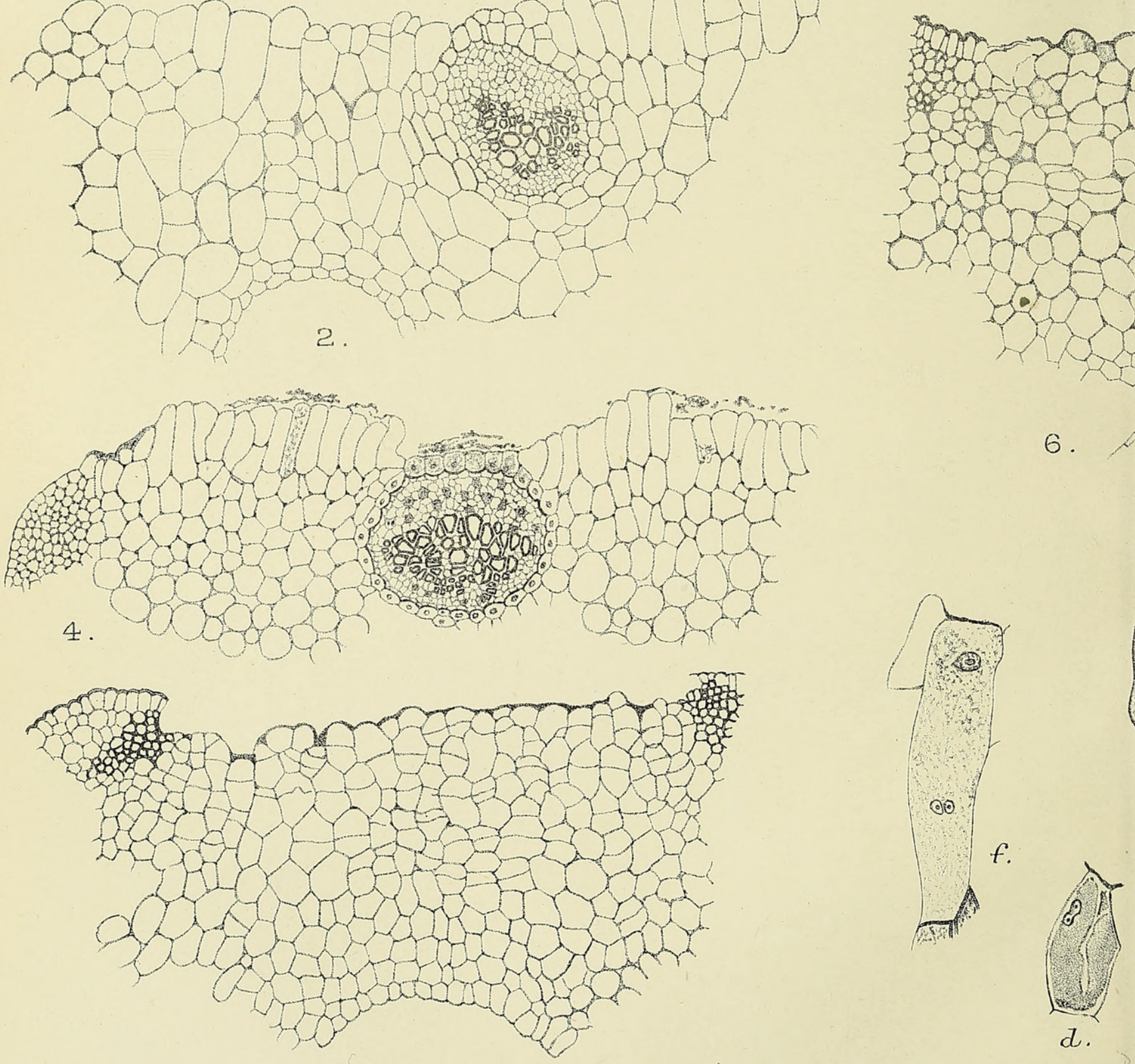

5.

H.S.H. del, 


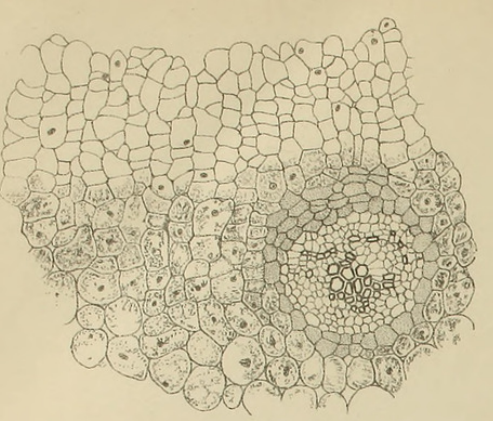

1
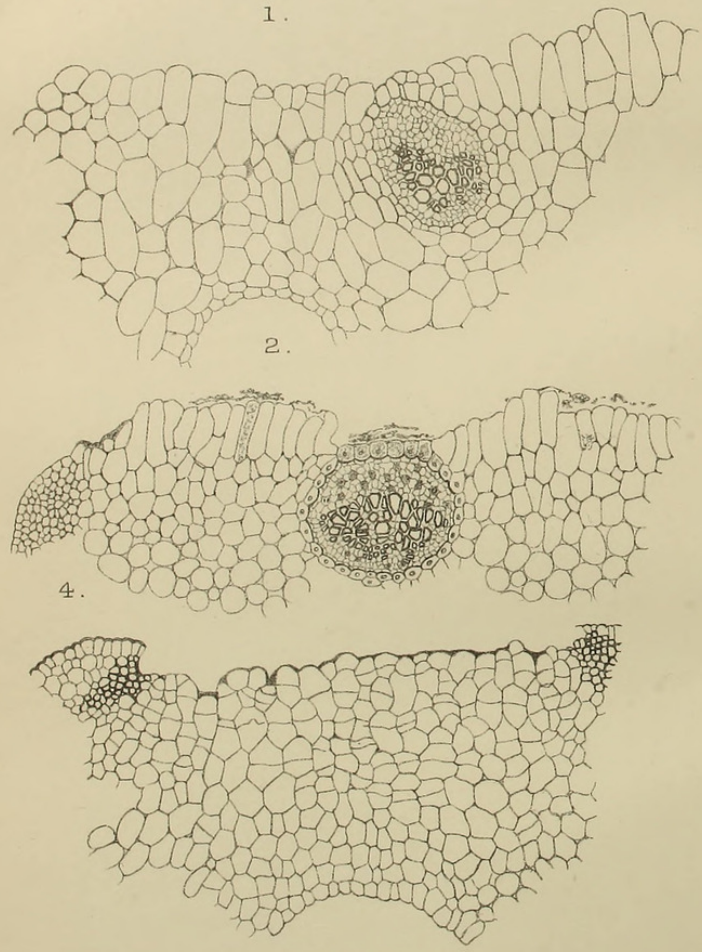

5.
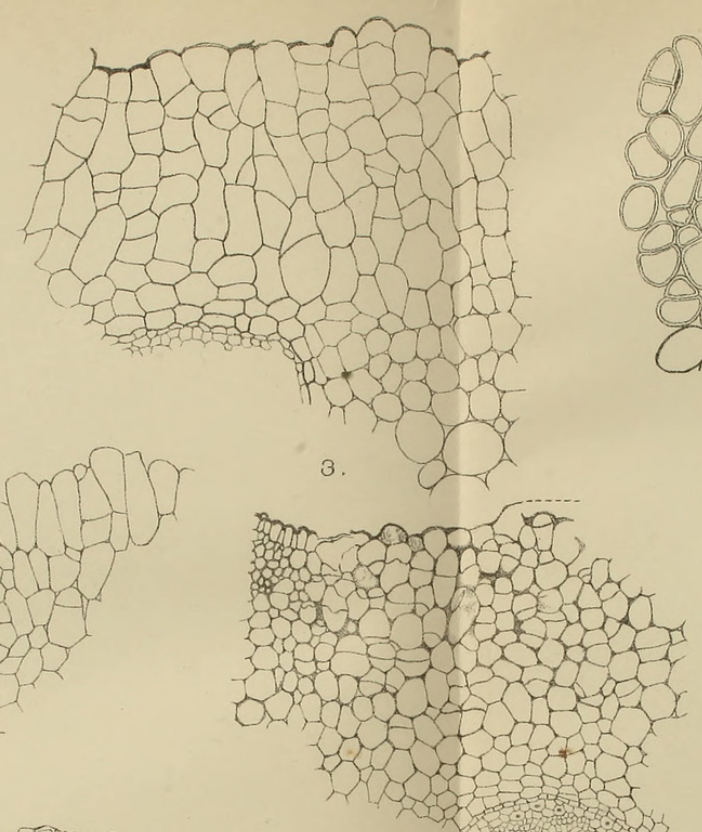

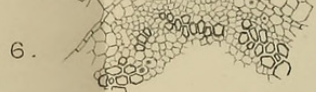

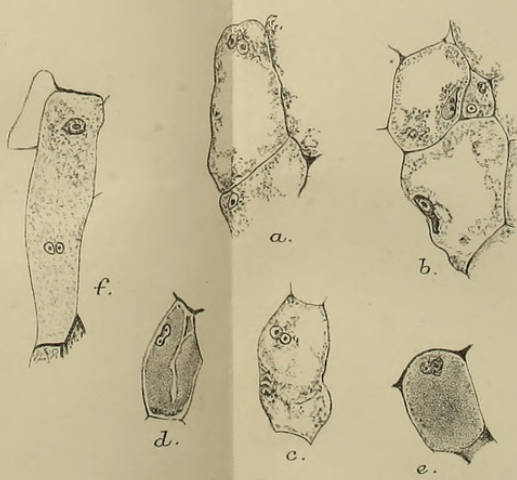

10.
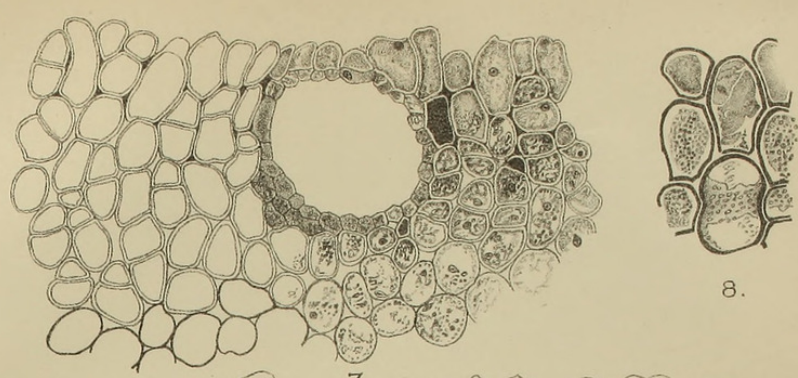

8.
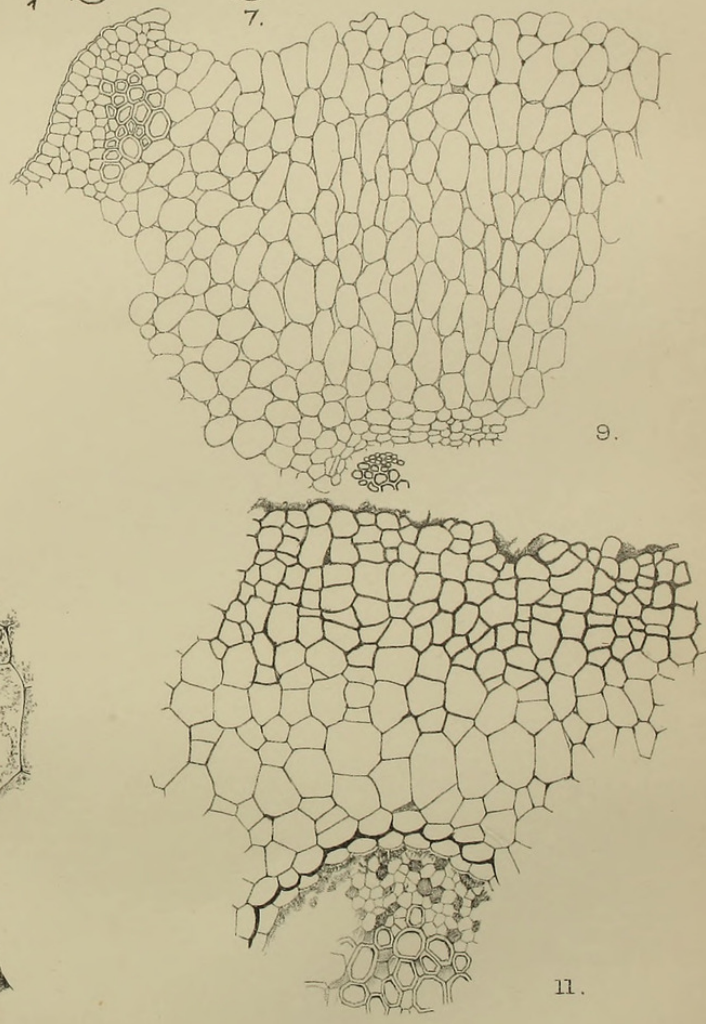

Huth, lith etimy 
Annals of Botany,

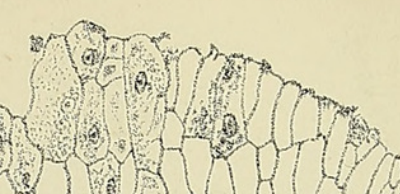

1
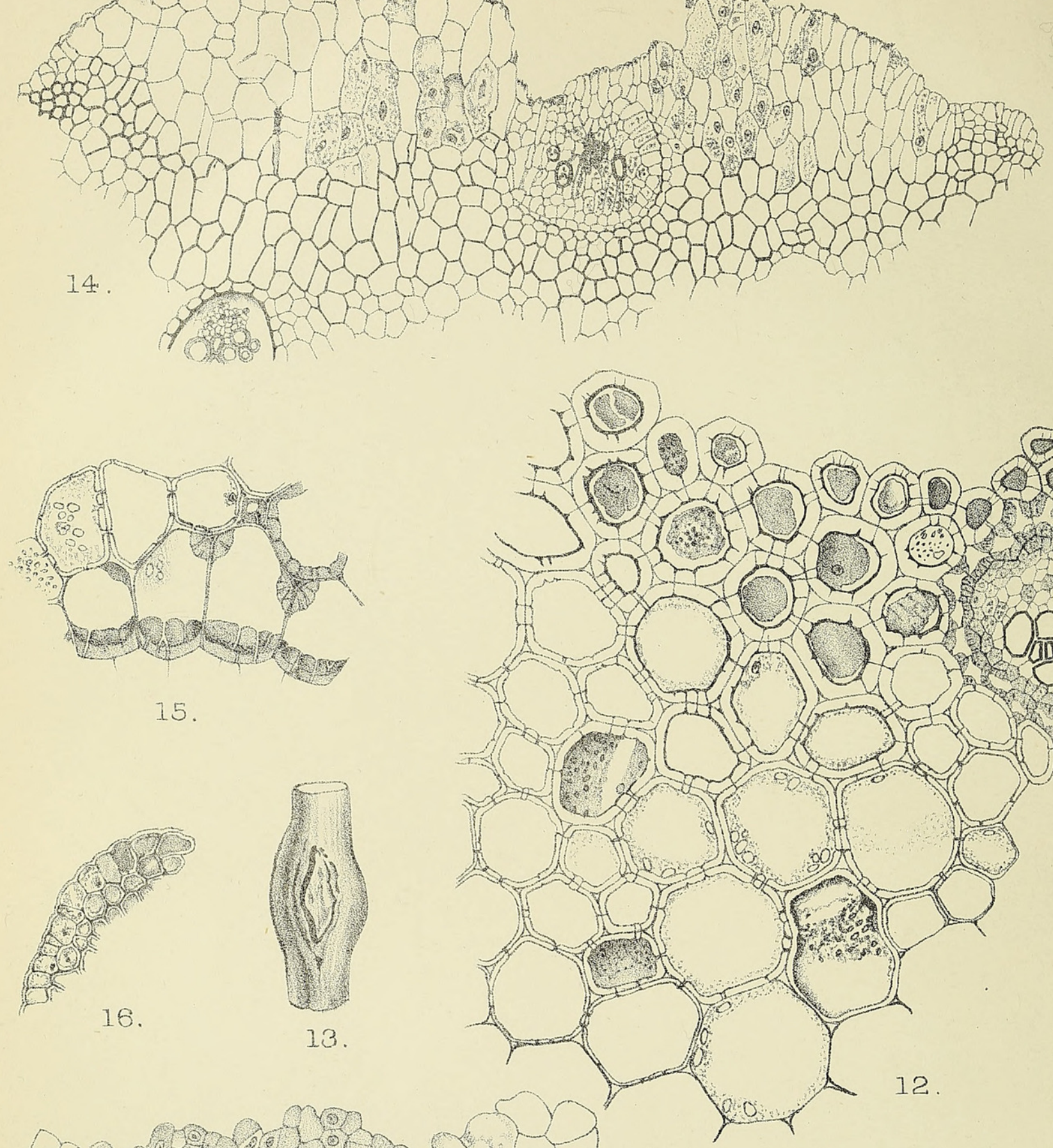

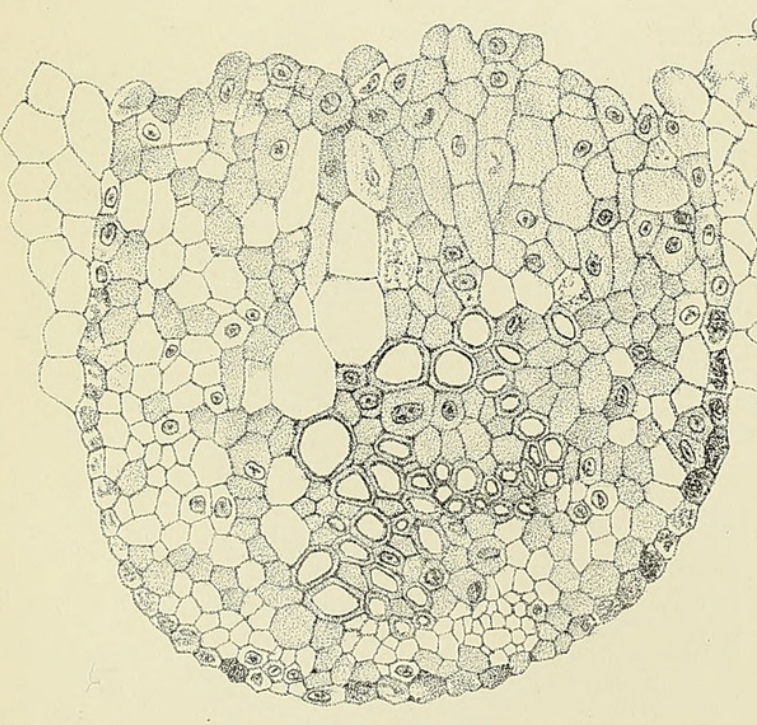

17.

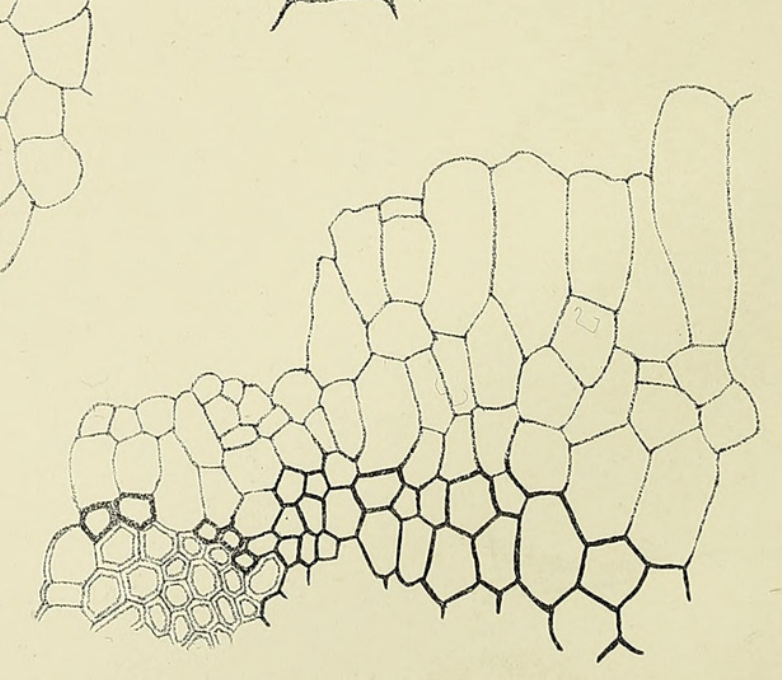

18. 


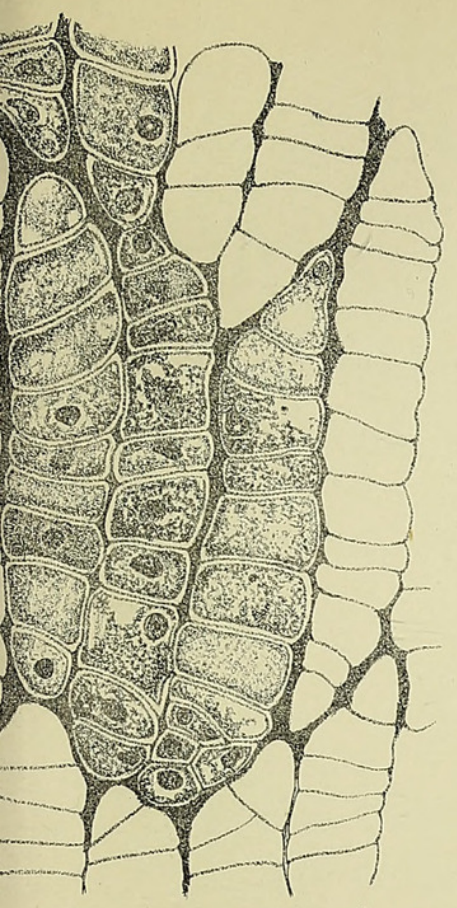

19.

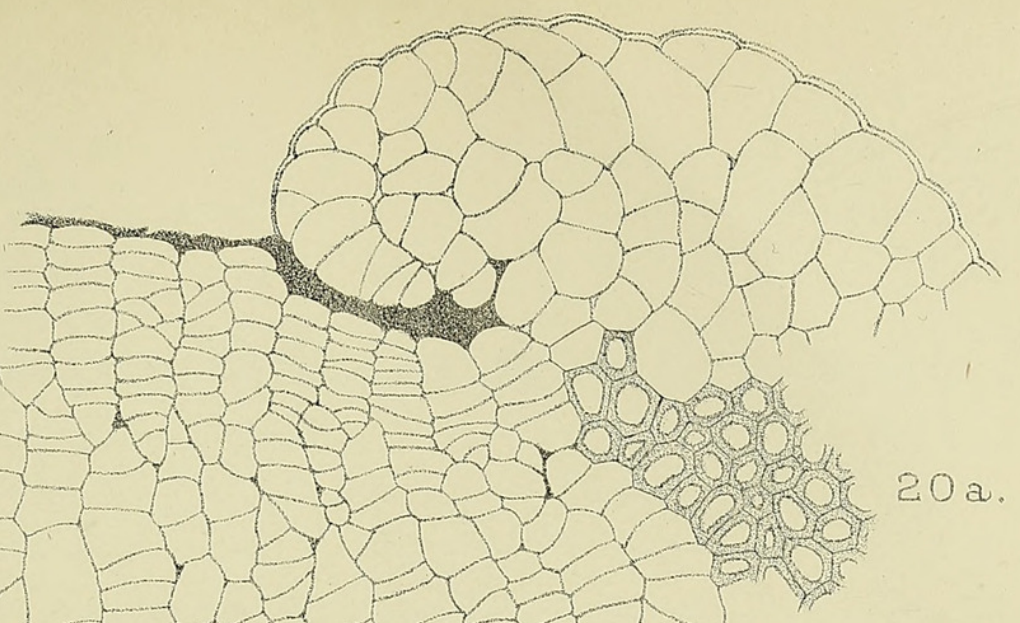

1.

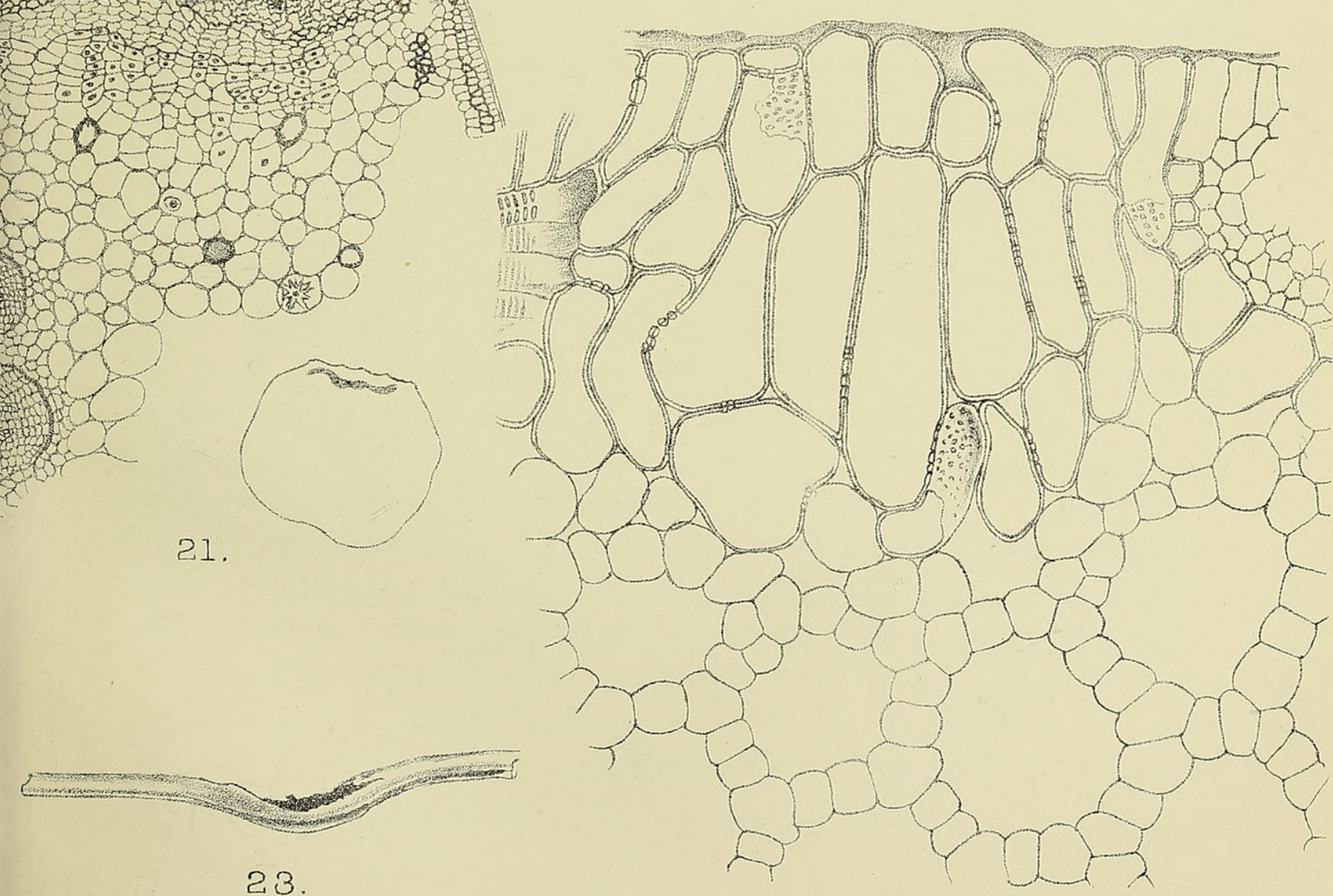

22. 


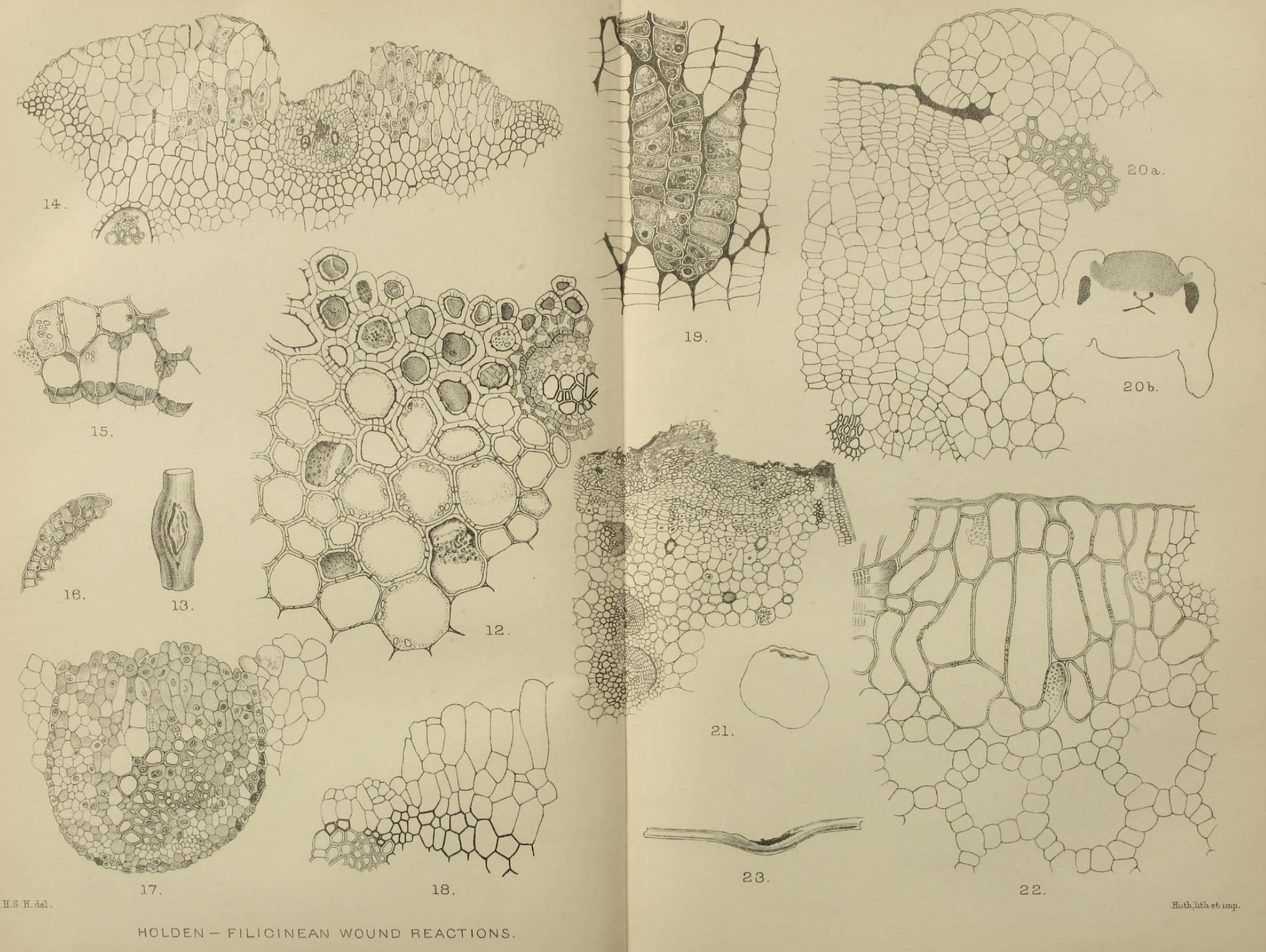




\section{$2 \mathrm{BHL}$ Biodiversity Heritage Library}

Holden, Henry Smith. 1912. "Some wound reactions in Filicinean petioles." Annals of botany 26, 777-793.

https://doi.org/10.1093/oxfordjournals.aob.a089416.

View This Item Online: https://www.biodiversitylibrary.org/item/236930

DOI: https://doi.org/10.1093/oxfordjournals.aob.a089416

Permalink: https://www.biodiversitylibrary.org/partpdf/319929

\section{Holding Institution}

Smithsonian Libraries

\section{Sponsored by}

Biodiversity Heritage Library

\section{Copyright \& Reuse}

Copyright Status: Not in copyright. The BHL knows of no copyright restrictions on this item.

This document was created from content at the Biodiversity Heritage Library, the world's largest open access digital library for biodiversity literature and archives. Visit BHL at https://www.biodiversitylibrary.org. 